\title{
THE “CORDIAL MAN": A LATIN AMERICAN CONCEPT IN THE BRAZILIAN ESSAY
}

\section{O "HOMEM CORDIAL": UM CONCEITO LATINO-AMERICANO NO ENSAIO BRASILEIRO}

\author{
Pedro Meira Monteiro ${ }^{1}$
}

\begin{abstract}
Resumo: Este artigo analisa Raízes do Brasil (1936), de Sérgio Buarque de Holanda, um livro seminal na tradição ensaística brasileira. A discussão começa com os limites da busca da especificidade nacional no Brasil, de modo a considerar a formação cultural brasileira como uma projeção de suas raízes ibéricas. Neste contexto, o "homem cordial" emerge como uma metáfora para a falta de espaço público no Brasil. Por um lado, o homem cordial é um produto dos debates na virada do século sobre o excepcionalismo latino-americano, uma figura quase capaz de suportar as desilusões do mundo moderno. Por outro lado, o homem cordial oferece uma janela a Buarque de Holanda para os limites do liberalism democrático e as tradições personalistas da América Latina: um impasse discutido extensivamente, mas nunca resolvido em Raízes do Brasil. Em última instância, o livro permite um questionamento mais profundo das pulsões coletivas e dos desejos individuais que, juntos, formam a matéria a que o populismo iria responder, uma forma política temporariamente capaz de atender as expectativas das pessoas.
\end{abstract}

Palavras-chave: Sérgio Buarque de Holanda (1902-1982), cultura e política no Brazil, ensaísmo, populismo, homem cordial.

\begin{abstract}
This article analyzes Sérgio Buarque de Holanda's Roots of Brazil (1936), a seminal book in the Brazilian essayist tradition. Discussion begins with the limits of Brazil's search for national specificity, so as to consider Brazilian cultural formation as a projection of its colonial Iberian roots. In this context, the "cordial man" emerges as a metaphor for the lack of public space in Brazil. On the one hand, the cordial man is a product of turn-of-the-century debates on Latin American exceptionalism, a figure almost capable of withstanding the disillusions of the modern world. On the other hand, the cordial man offers Buarque de Holanda a window into the limits of democratic liberalism and the personalistic political traditions of Latin America: an impasse discussed at length but never resolved in Roots of Brazil. Ultimately, the book permits a deeper questioning of the collective pulses and individual desires that, together, form the matter to which populism would respond, a political form temporarily capable of meeting the people's demands.
\end{abstract}

Keywords: Sérgio Buarque de Holanda (1902-1982), culture and politics in Brazil, essayism, populism, cordial man.

The essay is a literary genre with wide appeal and great intellectual importance in Brazilian history. Its origins, while difficult to trace, are often attributed to Montaigne in the European Renaissance, who deemed how something is said to be even more important than what is said. This is not a question of form over content, but instead of perceiving the essay as

\footnotetext{
${ }^{1}$ Princeton University, Princeton, New Jersey, USA; https://orcid.org/0000-0003-2536-2991; pmeira@princeton.edu
} 
a significant intervention precisely because it is a linguistic act, a dialogical and reflexive form, that positions the author not just in front of a social framework, but within it. The essay is antipositivist by nature, insomuch as its author is never protected by the political meaning of what he or she writes. The essay, it could be said, is a form of inscribing the subject into the very product of writing. We could even say that as essayists experiment freely with this "paradigm of insertion" - which Silviano Santiago overlays on the paradigm of national "formation," prevalent in the Brazilian essay - they are empowered to insert their tradition in global cultural discussions, rather than limiting themselves to Brazil's relative evolutionary lag.

In Brazil, the essay first emerged in the colonial period, closely associated with the press, and later solidified its form during the imperial period (1822-1889). With the advent of the Republic in 1889, the form took on a life of its own beyond the press, gaining even more steam during the Brazilian "modernist" movement of the 1920s and 1930s. This marked the formation of what Alexandre Eulalio has called the "Brazilian mentality deeply unsatisfied with the present reality" (56), at a moment when the cultural field served as a stage for the exchange of ideas. In a context in which experiences, both intimate and collective, were discussed widely, the quest for national specificity was often confused with grand fantasies of regional unity. There was a search for a movement contrary to the one detected by Florencia Garamuño in today's artistic sensibilities, which frequently evade rigid notions of "articulation" and "specificity" (15).

It was in this context - caught between the search for specificity and a genre that was slowly becoming open to imprecision - that the historian and literary critic Sérgio Buarque de Holanda (1902-1982) wrote Roots of Brazil, a work that would eventually join the pantheon of great Brazilian essays. For a while, Roots of Brazil was read as a "classic" of national interpretation, a testament to the country's origins, promises, and limitations. Published in 1936, and modified quite a bit for later editions, the book may be better understood now as an astute monument to the insufficiency of the national discourse. ${ }^{2}$

A contemporary reading of Roots of Brazil clarifies how collective identity has always been a fluid and necessarily relational construction, never a fixed image. By the same token, Brazil does not exist without the fantasy of being different, unique, and untranslatable. Moreover, the national banner - much like the national impulse to encompass all things in a single discourse - fails to account for the country's many internal differences. Brazil, in short, is always more (or less) than what can be said about it. In the clever words of the Argentinian composer Charly García: "la alegría no es solo brasileña" (happiness is not only Brazilian).

Many of the greatest essays of Brazilian interpretation, especially those under the modernist umbrella, emerged from the tensions between happiness and melancholy. The Week of Modern Art, hosted in São Paulo in 1922, is often considered the symbolic start of Brazilian modernism. This movement differs from its late-century Hispanic-American counterpart in that its authors mixed with the vanguard of the early $20^{\text {th }}$ century. Less interested in ossified "cultured" language, the Brazilian modernists experimented with language and strove to interpret life in Brazil beyond the lettered city, to use Angel Rama's phrase. In Mário de Andrade's Macunaima (1928), a seminal modernist work, the title character roams between city and forest in search of a miraculous jewel that has been stolen from him. In these wanderings, Macunaíma oscillates between the irresponsible happiness of someone determined to have fun and the melancholy of someone who has expended all his energy searching for pleasure. The book is dedicated to Paulo Prado, a patron of modernism and an author himself, whose Retrato do Brasil (Portrait of Brazil, 1928) portrays a Portuguese colonizer as a civilizing

\footnotetext{
${ }^{2}$ In this paper, I rely, with a few alterations, on the critical study that I prepared for the recent edition of Roots of Brazil published in Argentina (Meira Monteiro, "El hombre cordial"). The preface to that study drew upon reflections that would appear in my subsequent book, The Other Roots: Wandering Origins in Roots of Brazil and the Impasses of Modernity in Ibero-America.
} 
agent torn between greed, luxury, and sadness. In addition to aesthetic principles, both Andrade and Prado discuss what it means for a civilization to have colonial origins, and how collective energy could be siphoned towards a national project.

Published in 1936 in the midst of the Getúlio Vargas regime, Roots of Brazil may be understood as a response to the early modernist essays. The book delves into the Iberian "roots" that distinguish European presence in the tropics, while simultaneously probing the forces that allowed Brazilian society to form in the shadows of patriarchalism and slavery (abolished in 1888). The book is also a deep study of a political subject who would come to occupy a new space in society after the establishment of the Brazilian Republic, and whose characteristics were disputed by a range of political and cultural forces. Not by chance, the 1930s also marked the beginning of a number of significant national myths: the "happy" Brazilian; the discretely irresponsible citizen; the master of carnival, samba, and football. Consciously or not, Sérgio Buarque de Holanda confronts these myths as he questions the Portuguese colonial enterprise and, simultaneously, the civilization it built on oftentimes loose social cement and without the due funneling of individual energies towards collective construction. Could civilization be born of happiness and looseness? It is a question that pulses, silently, throughout Roots of Brazil.

In Roots of Brazil, Sérgio Buarque de Holanda proposes a series of differences between Spanish and Portuguese forms of colonization. While Spain focused more on establishing solid ground and firmly installing itself in the new landscape, Portugal was looser, less obsessed with rigidity (Holanda 161-207). Despite these postulated differences, Buarque de Holanda uses the broader, more generic "Iberian-American" culture as a lens for understanding the social space that formed in the New World through the meeting of European, indigenous, and African peoples.

One of the book's key concepts is the "cordial man," an idea now deeply embedded in the Brazilian collective imaginary. While the language used to define the concept is rather romantic — it imagines the people's "spirit" as their guide in societal progress — the cordial man does serve as a rather apt metaphor for the country's political impasse. Indeed, the cordial man is not a solution nor a conclusive definition. Readers who expect to find a perfect design or significant caricature soon discover that the cordial man's image unfolds in many others. Suddenly, we see ourselves, and this disturbing character, as players in a true "story of mismatches" (Cohn), as if we too were working through the difficulty — if not impossibility — of forming public sphere in Brazil.

The "cordial man" is not merely, nor even necessarily, affable or prudent, as evidenced by the controversy between Sérgio Buarque de Holanda and the poet Cassiano Ricardo. Soon after the publication of Roots of Brazil in 1936, Ricardo sought to box the concept in the authoritarian ideology of Getúlio Vargas' Estado Novo (1937-1945), which viewed Brazil's social relations as fundamentally sweet, as if the stiffness of conflicts could be mitigated immediately by some innate cooling mechanism in the soul of citizens. ${ }^{3}$

Meanwhile, in Sérgio Buarque de Holanda's interpretation, the cordial man lives off of his proximity to all things familiar. He is protected by his clan, shrouded in a bubble of kinship that fetters him in public space. Were he truly present in public space, he would be a citizen, just like anyone else, rather than a being tethered to familial ties. This entry in the world of the polis, of politics - an entry that turns an individual into an autonomous, independent, and selfresponsible citizen - is one of the principle dramas in Roots of Brazil. Like Antigone in Sophocles' tragedy, the cordial man obeys his blood ties because he believes they are sacred.

\footnotetext{
${ }^{3}$ For a more detailed analysis of the reception of the concept of cordiality by Estado Novo intellectuals, look to Feldman.
} 
He thus resists any of the City's measures to depersonalize public space, wary of any rule that places the collective ahead of the family (Holanda 246).

In this drama, fidelity takes center stage as the subject faces a crucial dilemma: to follow the will of the family or social inspiration? Transposed on the Latin American and global realities of modernization and urbanization, prevalent in the first decades of the $20^{\text {th }}$ century, the dilemma becomes even more acute. For it now requires investigation into what happened to the autonomous individual, to this figure who should be able to escape ancestral ties and take the cold plunge into modern individualism.

But where does the "cordial man" come from? Where does Sérgio Buarque de Holanda find this expression, and what does it carry inadvertently? What earlier issues and debates does the cordial man reveal and disguise?

The expression seems to first appear in Portuguese in a 1931 letter from the Brazilian poet Rui Ribeiro Couto (1898-1963), then in Marseilles, to the Mexican poet Alfonso Reyes (1889-1959). The letter would be published in Monterrey, the celebrated literary magazine run by Reyes during his stint as Mexican ambassador to Brazil from 1930 and 1936:

It is from the fusion of the Iberian man with this new land and its primitive races that an (Latin) "American sensibility" may emerge, a new race, product of a culture and a pure intuition, the cordial man. This, as I see it, is what our America is giving to the world: the cordial man.

While Sérgio Buarque de Holanda's tone is less celebratory than Ribeiro Couto's, the above passage reveals the first sparks of a rather complex concept. On the one hand, cordiality points to an impasse in the formation of public space, which is dependent on the subject's depersonalization and, subsequently, transformation into a citizen. On the other hand, cordiality is clearly idealized as an Iberian, or "Latin," characteristic.

The genealogy of the expression "cordial man" stretches back quite a bit. It is in "The Triumph of Caliban," written by the Nicaraguan poet Rubén Darío, and published by the Argentinian newspaper La Nación in the heat of the 1898 armed intervention by the United States in the Caribbean, that the cordial man appears to have made his print debut. In the article, Darío recalls a night in Buenos Aires when Roque Sáenz Peña, during a conference at the La Victoria theater, sponsored by Club Español, reported on the Spanish-American War:

In his speech at this gathering, the ever-cordial [varón cordial] Sáenz Peña stood and spoke as a statesman. He repeated what he has always spoken of - his conception of the peril presented by those boa-constrictor jaws, ready to swallow still more, even after the enormous dinner it made of Texas; the greed of the Anglo-Saxon, the appetite the Yankee has shown, the political infamy of the government of the North; and how useful, how necessary it is for the Hispanic nationalities of the Americas to be prepared for the boa constrictor's next strike. Only one soul has been as farsighted in this matter, as farsighted and persistent, as Sáenz Peña, and that soul was - time's strange irony! - the father of free Cuba, José Martí. Martí never ceased urging the nations of his blood that they be careful with those men of prey, that they not be lured into those pan-American schemes, but rather look to the Yankee businessmen's traps and snares. What would Martí say today when he saw that under the colors of aid to the troubled Pearl the monster was swallowing it, oyster and all? In the speech I have referred to, I have said that the man of cordiality [el hombre cordial] and the statesman were arm-in-arm. That 
Sáenz Peña is both things is attested to by his entire life. Such a man should appear in defense of the noblest of nations, fallen into the booty-sack of those Yankees [caída al bote de esos yangüeses], in defense of the unarmed gentleman who accepts the duel with the dynamite-carrying, mechanic-overall-wearing Goliath (Darío 86-87). ${ }^{4}$

The boa constrictor's jaws symbolize North America's imperial greed, which the mask of benevolent Pan-Americanism fails to hide, at least in the eyes of those who seek to identify the United States as the monster of the North, a threat to the liberty of the Southern world. It is in this context that Sáenz Peña (not yet president of Argentina) emerges in defense of the unarmed caballero - a reference to Don Quixote. ${ }^{5}$ Much like José Martí, he seems to see through the Yankees, to understand the great trap they are setting. Protecting the Spanish motherland and its Latin progeny, the statesman appears to be a truly "cordial man."

Though hard to determine whether this is the exact genealogy of "cordial man," it is certainly of interest how the reaction to the spectral North triggered the image of a politician wreathed in cordiality - a characteristic that points to the legacy later celebrated by Ribeiro Couto, and which Sérgio Buarque de Holanda molded into a powerful metaphor for understanding political relations between Latin Americans or, more specifically, Brazilians.

From this mix of Hispanic-Americans and Brazilians, however, stands out the Mexican thinker José Vasconcelos (1882-1959). In The Cosmic Race (1925), his renowned take on Latin American exceptionalism, Vasconcelos writes that we find "a thousand bridges... for the sincere and cordial fusion of all races," as well as a "sensitive and ample heart...that embraces and contains everything and is moved with sympathy, but, full of vigor, imposes new laws upon the world." Cordial, after all, comes from the Latin cor, cordis, meaning heart. This "cosmic" Latin American formation would herald a civilizational "scherzo," in which all come together and mingle - unlike the "allegro" of the Anglo-Saxon march, uninterrupted and vigorous, capable of steamrolling the Other before taking any time to assimilate it (Vasconcelos 16-18).

This is not to draw a direct line between Sérgio Buarque de Holanda and Rubén Darío, by way of Ribeiro Couto and his dialogue with Alfonso Reyes, and passing through Vasconcelos' ideological tang (which makes abundant use of the word "cordial" in reference to Brazil). But even assuming no direct line, looking back to the broad spectrum of Latin American intellectual debates — including those around arielismo - helps deepen our understanding of "cordiality" as a form of sociability that contrasts with the supposed North American iciness. The debates around arielismo cannot be summarized merely in José Enrique Rodó's Ariel (1900), a rereading of Shakespearean motives (Ariel, Caliban, and Prospero), which itself draws upon the work of Ernest Renan in revolutionary France. As Carlos Jáuregui has shown, these debates bring us back to Rubén Darío and, from there, to the French occultist and founder of the Rosicrucian order, Joséphin Peladan (444). All that, and there is still much to be unearthed in the little-explored terrain of Latin American exception.

For these authors who dreamed of the superiority of the Latin American subcontinent, the United States is an example of an undesirable diversion on the path towards civilizational advancement. In valuing manual labor, so ceaseless and alienating, to such an extreme, North Americans deified a form of individualism bereft of feeling. Meanwhile, in the "Latin" quadrant, the soul still could delight in the creative leisure of elevated spirits — or rather, elevated and misunderstood, fitting of the elitist and post-romantic tastes of the late $19^{\text {th }}$ century, a period

\footnotetext{
${ }^{4}$ Here, and in a few other moments, I use Flora Thomson-DeVeaux's English translations (Meira Monteiro, The Other Roots 127-128).

5 Darío's mention of the "Yankees" is a reference to the passage where Don Quixote and Sancho react to the "yangüeses" beating of Rocinante, who in turn ingratiated himself with their mares. The result is a fight between David and Golliath: Sancho and Quixote against a hundred men, who ultimately wallop the hidalgo and his faithful squire (Cervantes 159-167).
}

Rev. Bras. Lit. Comp. Niterói, v. 22, n. 41, pp. 27-36, set. /dez. 2020

https://doi.org/10.1590/2596-304X20202241pmm 
haunted by the ghost of regression. Indeed, it would not take long for Oswald Spengler, in Germany — the same country where Sérgio Buarque de Holanda lived from 1929 and 1930 and first conceived of Roots of Brazil - to pen The Decline of the West, published between 1918 and 1923, an agonized response to the supposed disorganization of modern society.

Stepping back, we may see that debates on Brazilian identity - obsessively and claustrophobically self-referential - are connected to larger discussions about modern decay and Latin America's role both in resisting the world's disillusionment and in protecting, like a secret, all that the world was losing. In the Hispanic-American context, the "modernism" that emerged in the late $19^{\text {th }}$ century was driven by questions of loss, rather than emergence. While renewal was indeed evident in the areas of language and literary sensibility, Hispanic-American modernism paid more attention to what was breaking down than to what was being built.

In the Uruguayan writer José Enrique Rodó (1871-1917), this problem appears coded in his references to the eclipsing of the spirit in a world where heroes tend to fade away:

Great civilizations, great nations, in the historical sense, are those that, once their time has passed, leave vibrating throughout eternity the harmony of their spirit and imprint their heritage upon posterity - as Carlyle said of his heroes - like a new and divine proportion in the sum of things. In Goethe's Faust, when Helena, called from the realm of night, again descends into the shadow of Hades, she leaves Faust her tunic and her veil. These vestments are not the goddess herself but, as she has worn them, they are imbued with her supreme divinity and have the virtue of elevating whoever possesses them above all vulgarity (219-220).

While it would be unfair to reduce Rodó to the erudite - elitist and aestheticizing gesture of Ariel, it is worth recognizing how seductive it was for Sérgio Buarque de Holanda, just 17 years old in April 1920, to think about the "intellectual emancipation" of Latin America, a topic he writes about in Correio Paulistano. One of the first names evoked in the article is the Peruvian author Francisco García Calderón, a first-class arielista, who the young Buarque de Holanda tells us is dedicated to the "complete spiritual emancipation of the New World, especially the part where the language of Cervantes holds sway" (Holanda, O espírito e a letra 36).

In May 1920, now 18 years old, Buarque de Holanda publishes a review of Ariel that also serves as an obituary for José Enrique Rodó, who passed away a few years earlier. The article is a cry against the decay of nations that kowtowed to the grandness and progress of exotic "races." Buarque de Holanda agrees with Rodó's distrust of North Americans, viewing "Yankee utilitarianism" as the biggest villain. He attributes this fact, however, to the U.S.'s republican condition, giving us a clear glimpse into his earlier monarchist ideals (Holanda, $O$ espírito e a letra 42-46). ${ }^{6}$

In Buarque de Holanda's review, Rodó's elitism takes on a broad spectrum of meaning:

Utilitarianism and a preoccupation with earning money, auri sacra fames, have conquered North Americans to the detriment of their intellectual spirit, political morality, and even individual liberty. This led Schopenhauer to describe them as the proletarians of humanity. Their very character, he says, is vulgarity in all its forms: moral, intellectual, [and] aesthetic, a vulgarity that is patent not only in private life, but in public life as well. The author of Die Welt als Wille attributed this vulgarity in part to the republican Constitution of the United States and in part to its origin, having been

\footnotetext{
${ }^{6}$ For Sérgio Buarque de Holanda's young monarchist views, read Eugênio. For the importance of Rodó to the young author, read Newcomb 183-210.
}

Rev. Bras. Lit. Comp. Niterói, v. 22, n. 41, pp. 27-36, set. /dez. 2020

https://doi.org/10.1590/2596-304X20202241pmm 
originally a penal colony, and having among its ancestors "men who had reason to flee from Europe" (Holanda, $O$ espírito e a letra 43).

It would be an error to associate these ideas with the critique of authoritarian thought that Buarque de Holanda would elaborate sixteen years later in Roots of Brazil. Still, it is worth noting the strong impression that the Latin American cause and Rodó's elitism make on the eighteen-year-old writer. Though watered down, North America's "cold, prosaic empiricism" reappears in the Weberian theses that provide the foundation for Sérgio Buarque de Holanda's argument. Moreover, in the chapter on the "cordial man," he returns to the "contribution to the world" proposed by Ribeiro Couto in his dialogue with the diplomat and essayist Alfonso Reyes. $^{7}$

But the Latin American circle of Buarque de Holanda's ideas extends even further, perhaps coming to a close in Buenos Aires a few decades earlier with Rubén Darío's praise of Roque Sáenz Peña in La Nación. Darío, much like the ever-present ghost of José Martí, appears ready to erect a civilization that could withstand the irritating coldness, objectivity, and practicality of modern society.

This Latin American network of imagination becomes more sprawling if we take into account the last chapter of Roots of Brazil, which pays special attention to Hispanic-American politics. It is true that the original book, published in 1936, would be significantly altered for its second edition in 1948, suggesting Buarque de Holanda's continued reconsideration of his theses. Nevertheless, Buarque de Holanda's deep mistrust of the liberal political matrix is apparent even in the first edition. In reference to the José Batlle y Ordóñez presidency in Uruguay, he writes: "rationalism exceeded its limits" when its "concepts" were "erected as a supreme rule," and thus separated "irremediably from life," creating "with them a logical, homogenous, and ahistorical system." Such a political experiment - overly "logical" and completely distant from "life" — would elevate "democratic impersonalism" to its maximum power. At this moment, however, Buarque de Holanda argues that "caudillismo" belongs to the same circle of ideas as "liberalism," being merely the "negative form" of the liberal thesis (Holanda, Raizes do Brasil 316-319).

This was the shadow of the Interwar period, which loomed and advanced:

Thus, Rousseau, the father of the social contract, belongs to the family of Hobbes, the father of the Leviathan state; both come from the same nest. The negation of liberalism, which was unconscious in a Rosas, a Melgarejo, or a Porfirio Díaz, is affirmed today as a body of doctrine in European fascism, which is nothing more than a critique of liberalism in its parliamentary form erected on a positive political system. The victory of democratic doctrine will only really be possible when its antithesis, liberalismcaudillismo, is overcome (Holanda, Raízes do Brasil 316-317).

From Chile to Costa Rica, personalism would have erected itself as a "positive force," in which "the slogans of liberal democracy seem to be purely decorative or declamatory concepts, without deep roots in reality." As if announcing the thesis that liberal ideas would always be "out of place" in Brazil, as Roberto Schwarz notes, Buarque de Holanda maintains that the "idea of a sort of immaterial and impersonal entity, hovering over individuals and presiding over our destinies, is hardly intelligible to the peoples of Latin America" (Holanda, Raizes do Brasil 323-324).

\footnotetext{
${ }^{7}$ On the Weberian presence in Sérgio Buarque de Holanda's imagery, look to Meira Monteiro, A queda do aventureiro.
} 
The problem was the connection between society and the state, which liberalism tended to turn neutral and subordinate to the economy. Liberal thought lacked — in the words of Carl Schmitt, partially endorsed by Sérgio Buarque de Holanda - a "positive theory of the state." Significantly, Buarque de Holanda's laudatory reference to Schmitt as the "illustrious professor of Public Law from the University of Bonn" (Raizes do Brasil 334) would disappear from editions published after 1948, as the German author's name became indelibly associated with Nazism.

Independent of the erasure of anti-liberalism in the "definitive" edition of Roots of Brazil, the problem would remain bothersome: what political principle could be used to establish collective construction? And why, after the First World War, were these "doctrines that preach the utmost submission of the individual to the state" reborn with newfound dynamism?

$* * *$

In a 1935 article, Sérgio Buarque de Holanda briefly summarizes Carl Schmitt's theses. The following year, this summary would develop into Roots of Brazil's conclusion, where Buarque de Holanda affirms there to be little doubt that "politics itself represents an irrational activity, that stems from the obscure, unconscious regions of man" (Holanda, Raízes de Sérgio Buarque de Holanda 299). Using the tensions between "friend" and "enemy" as a template for policy, Schmitt had cast a shadow of suspicion on the clear principles of representative liberal democracy, which he viewed as often ignoring the troubled and irrational nucleus of politics.

In discussing traces we might identify as "psychological," the author of Roots of Brazil is in fact launching himself into a discussion of political order. For the matter he sets forth to tackle is a hot-button issue in the Interwar period: the individual's position and role in addressing imperative collective needs. The book is written in the heat of Latin American populism, a period that forged political models capable of establishing a short-circuit in the very idea of representation. To put it schematically, the subject-leader compromise would make secondary the mediations of liberal politics, as well as the chain of representation sacralized by those politics. As such, it is perhaps not overkill to view the "cordial man" as a dramatized form of the political impasses between the ghosts of totalitarianism, which Sérgio Buarque de Holanda firmly rejects, and values of liberalism, which he struggles to defend enthusiastically. His views on the shortcomings of liberalism are especially clear in the first edition of Roots of Brazil, when he bemoans the "fraudulent" character of "liberal mythology," adjectives that notably disappear in editions published after World War II (Holanda, Raízes do Brasil 327).

It is up to the reader to decide whether there is an analysis of populism lurking beneath Buarque de Holanda's reflections from 1936. Put in contemporary theoretical terms, this is a question of perceiving popular demands as crystalized in a "discursive identity," and of understanding the "people" of populism as intimately tied to the momentary precipitation of their will. This has nothing to do with some magical moment, the miraculous disappearance of the lines separating the leader and the people, but rather with something much closer to a complex "identification," in the psychoanalytic sense (Laclau 93-94). Nor does it have anything to do with the conception of politics as a simple mediation between diverse social demands. Every social demand has a gap that must be filled. Its immediate - not eternal, nor absolute — fulfillment is a quintessentially political job.

To tackle the problem theoretically and politically, it is worth remembering that the indefinable character and contingency of collective demands should be understood not as an obstacle to change, but perhaps as its motor. This may very well be the meaning of the final paragraph of Roots of Brazil, where vague expressions, like "our own spontaneous rhythm" and "more intimate and essential world," appear to curb the technocratic and authoritarian delirium 
of those who seek to impose "ingenious formulas" that will "someday" bring us "face to face with our reality" (Holanda, Raízes do Brasil 331).

While Sérgio Buarque de Holanda resisted using social class as an analytic category, his definition of the subject of those constantly transforming collective demands - and of the "us" inherent in "our reality" — is irrefutably controversial. Roots of Brazil's oftentimes paradoxical and incomplete theses stem from a central question: how to include vast contingents of the population in politics, especially when over four decades of the republican regime were incapable of reversing the grim legacy of slavery, which had continued through most of the $19^{\text {th }}$ century? In any case, social inclusion brought Brazil - and perhaps still brings Brazil - face to face with the limits on liberal politics. If it is true that all change, so to speak, begets a demand for a new law, then we must also remember that all new laws constitute the founding of a "state of exception." Beyond the figurative meaning of this "exception," we must dig into the meaning of historical change, so as to understand the need for breaking the vicious cycle that, under the warden of the liberal-democratic state, reproduces social exclusion ad nauseam (Ramirez 175182).

The terrain is marshy, and there is much to be studied. Yet, as in the case of the demon of Descartes, evoked in the conclusion to Roots of Brazil, "simple truths" are merely hidden from sight. No one dares to realize that "superior forms of society" should derive from social forces and demands that emanate from the "specific needs" of the collective, and never from the "capricious choices" of few (Holanda, Raizes do Brasil 331).

The "specificity" of popular demands is an open-ended, slippery, and provocative matter, one that seems to hover in expectation of some signifier, in the linguistic sense, wherein the collective, in a sudden and irresistible flash, might finally reveal itself. Ultimately, we are left asking whether or not to resist the appeal of those "demands." In one way or another, Roots of Brazil teaches us how to see the people - a term that would become central to the rhetorical engineering of politics, and a difficult, and potentially impossible, subject to avoid or define.

Translated by Dylan Blau Edelstein

\section{WORKS CITED:}

ANDRADE, Mário de. Macunaíma: o herói sem nenhum caráter. São Paulo: Ubu, 2017. CERVANTES, Miguel de. Don Quijote de la Mancha, edited by Francisco Rico. Barcelona: Editorial Crítica, 2001.

COHN, Gabriel. "O pensador do desterro." Folha de S.Paulo, 23 June 2002, caderno mais!, pp. $10-11$.

COUTO, Rui Ribeiro. "El hombre cordial, producto americano.” Holanda, Sérgio Buarque de. Raízes do Brasil, edited by Ricardo Benzaquen de Araújo and Lilia Moritz Schwarcz. São Paulo: Companhia das Letras, 2006, p. 397.

DARÍO, Rubén. Prosas políticas, edited by Jorge Eduardo Arellano. Managua: Ministerio de Cultura, 1983.

EUGÊNIO, João Kennedy. "Um horizonte de autenticidade. Sérgio Buarque de Holanda: monarquista, modernista, romântico (1920-1935)." Sérgio Buarque de Holanda: perspectivas, edited by Pedro Meira Monteiro and João Kennedy Eugênio. Rio de Janeiro/ Campinas: Eduerj/ Editora da Unicamp, 2008, pp. 425-459.

EULALIO, Alexandre. Escritos, edited by Berta Waldman and Luiz Dantas. São Paulo/ Campinas: Edunesp/ Editora da Unicamp, 1992.

FELDMAN, Luiz. Clássico por amadurecimento: estudos sobre Raízes do Brasil. Rio de Janeiro, Topbooks, 2016. 
GARRAMUÑO, Florencia. Frutos estranhos: sobre a inespecificidade na estética contemporânea. Rio de Janeiro, Rocco, 2014.

HOLANDA, Sérgio Buarque de. O espírito e a letra: estudos de crítica literária I (19201947), edited by Antonio Arnoni Prado. São Paulo: Companhia das Letras, 1996.

. Raízes de Sérgio Buarque de Holanda, edited by Francisco de Assis Barbosa. Rio de

Janeiro: Rocco, 1988.

. Raízes do Brasil: edição crítica, edited by Pedro Meira Monteiro and Lilia Moritz

Schwarcz. São Paulo: Companhia das Letras, 2016.

JÁUREGUI, Carlos. "Calibán: ícono del 98. A propósito de un artículo de Rubén Darío."

Revista Iberoamericana, vol. 64, no. 184-185, 1998, pp. 441-449.

LACLAU, Ernesto. On Populist Reason. London: Verso, 2007.

MEIRA MONTEIRO, Pedro. "El hombre cordial: un concepto latino-americano." Afterword.

Raíces del Brasil, by Sérgio Buarque de Holanda. Buenos Aires, Corregidor, 2016.

. A queda do aventureiro: aventura, cordialidade e os "novos tempos" em Raízes do

Brasil. Campinas: Editora da Unicamp, 1999.

. The Other Roots: Wandering Origins in Roots of Brazil and the Impasses of

Modernity in Ibero-America. Translated by Flora Thomson-DeVeaux. Notre Dame:

University of Notre Dame Press, 2017.

MONTAIGNE, Michel de. "Des Livres." Les Essais. Edited by P. Villey and V.-L. Saulnier.

Online edition by P. Desan, University of Chicago,

https://artflsrv03.uchicago.edu/philologic4/montessaisvilley/navigate/1/4/11/. Accessed 28

November 2019.

NEWCOMB, Robert P. Nossa and Nuestra América: Inter-American Dialogues. West

Lafayette: Purdue University Press, 2012.

PRADO, Paulo. Retrato do Brasil: ensaio sobre a tristeza brasileira. São Paulo: Companhia das Letras, 2012.

RAMA, Ángel. La ciudad letrada. Hannover: Ediciones del Norte, 1984.

RAMIREZ, Paulo Niccoli. Sérgio Buarque de Holanda e a dialética da cordialidade. São

Paulo: Educ, 2011.

RODÓ, José Enrique. Ariel. Madrid: Cátedra, 2004.

SANTIAGO, Silviano. "Formação e inserção.” O Estado de São Paulo, 26 May 2012,

https://cultura.estadao.com.br/noticias/geral,formacao-e-insercao-imp-,878251. Accessed 28

November 2019.

SCHWARZ, Roberto. As ideias fora do lugar. São Paulo: Penguin Companhia, 2014.

SPENGLER, Osvald. The Decline of the West. Translated by C. F. Atkinson. New York: A.

Knopf, 1926-1928, 2 vol.

VASCONCELOS, José. La raza cósmica. México, DF: Editorial Porrúa, 2003.

Pedro Meira Monteiro é Professor Titular do Departamento de Espanhol e Português da Universidade de Princeton - EUA. Mais informações em https://spo.princeton.edu/people/pedro-meira-monteiro

Submetido em 23/04/2020

Aprovado em 23/06/2020 